\title{
THE PREDICTING SUCCESS FACTORS OF MOBILE APPLICATIONS DEVELOPMENT: ORGANIZATIONAL PERSPECTIVES
}

\author{
Chinedu Wilfred Okonkwo and Magda Huisman \\ North-West University, Unit for Business Mathematics and Informatics \\ Private Bag X6001, Potchefstroom, South Africa, 2520
}

\begin{abstract}
Mobile applications (mobile apps) development is one of the fastest evolving technological innovations across the globe. The immense growth of mobile apps development can be attributed to the incredible rate of growth of mobile technology and its propagation into every facet of modern life. The success of these applications lies within some predicting success factors with respect to stakeholders' expectations and perceptions. Researchers have attempted to identify the factors influencing mobile apps development. However, these researches were mostly conducted from the individual software developers' perspective. This paper presents an empirical investigation of the significance of these predicting factors of mobile apps development from different organizations' perspectives. A survey was conducted among different organizations that are involved in one way or another in the development of mobile apps. The findings showed that individual development skills, functionality, mobile devices specifications, use of a software development kit, back-end integration, portability, web and network integration, and the use of a system development methodology are the predicting success factors of mobile apps development whereas open source technology is not. Furthermore, different types of organizations have different perceptions of how important a predicting success factor is in the development of mobile apps.
\end{abstract}

\section{KEYWORDS}

Mobile Applications Development, Predicting Success Factors, Organizations, Perception, Mobile Applications

\section{INTRODUCTION}

In the past couple of years, there has been tremendous growth in the development of mobile applications (mobile apps). The entry of mobile devices into the market has triggered the development of various kinds of mobile apps. Mobile technologies have created a major shift in the way we perform our daily activities. In today's fast-paced world, mobile services are the engine that powers virtually all activities including education, communications, economics, commerce, banking, politics, healthcare, agriculture and social activities (Qiang et al. (2011), Murugesan (2013), Hellstrom and Troften (2010), El-Hussein and Cronje (2010)).

Mobile apps development is the procedure by which application software is designed and created to facilitate the operations of mobile technologies services (Qiang et al. (2011), McNamara (2009)). The rapid growth of the mobile phone market and technological advancements has resulted in a high demand for mobile apps. Consequently, the advancement in the mobile apps development field is unprecedented.

The search for success factors is not new in information systems research. Several studies have been conducted to discover the factors that are significant to be considered for the development of mobile apps (Wasserman (2010), Siau et al. (2010), He and Xu (2014), Corral et al. (2013), Capretz and Ahmed (2010), Ahmed et al. (2013)). These authors have emphasized the need to identify the predicting success factors (PSFs) that can be used to develop successful mobile applications.

Every software project has a unique purpose and unique features, thus the developmental process and factors to be considered may vary with the regards to the stakeholder's expectations and purposes. There are different perceptions about a project's success, as well as how and when the success is measured (Toor and Ogunlana (2009)). The design and development of a mobile app depend on the stakeholder's requirements 
and expected services. There exist several kinds of mobile apps with different functionalities including mobile learning, mobile health, mobile agriculture, mobile commerce, mobile government, mobile banking and mobile social activities (Qiang et al. (2011), Murugesan (2013), Hellstrom and Troften (2010), Mutula and Mosterd (2010), GMSA (2015)). These mobile apps are developed by or for different organizations with their respective objectives. The measurement of their successes are also different. It is, therefore, observed that most of the studies that identified the PSFs are context-specific and fragmented. The obtained results are based on a specific kind of mobile app like the PSFs of developing mobile banking (Noor (2011)), mobile learning (Papanikolaou and Mavromoustakos (2006)), mobile commerce (Feng et al. (2006)), and mobile health (Chatterjee et al. (2009)) applications.

Although, most of the identified PSFs are important, what is a valued PSF to one organization might not be valued by the other organization. Each of these organizations operates on a different contextual environment with unique objectives and their mobile apps are uniquely designed to support their operational services. It is necessary to bring all these PSFs together to examine their degree of significance to the different kinds of mobile apps as it concerns different organizations.

There is a need for more studies on this area; hence, this paper intends to address two major issues, 1) to capture all the generally identified PSFs and 2) to investigate and find the level of importance of each PSF from the perspective of different types of organizations including educational institutions, financial institutions, telecommunication companies and software development companies.

\section{BACKGROUND INFORMATION}

Software application development has been steadily growing and is of great importance to the advancement of information systems and communication technology. The development of mobile apps involves formalized methods or system development methodologies which is the combination of a software development approach, method, process and techniques (Huisman and Iivari (2006), Holzer and Ondrus (2011)). Mobile app development provides a platform for creating applications that combine the functionality of the mobile telephone as a traditional communication device with the information systems' functionality of computing which include data collection, data processing, information access, transmission of text, voice and chatting (Murugesan (2013)). This has indeed led to the increased usage of mobile apps and hence the need for the everyday development of applications to meet the needs of mobile phone users. It, therefore, became imperative for application developers to concentrate on creating mobile apps that provide similar applications that used to be run on PCs for mobile devices.

Currently, mobile apps development is significantly higher than ever before. As a result, software development companies are constantly seeking a suitable development platform for mobile apps development which can support the current and future needs of their projects (Olavsrud (2012)). The creation of a successful mobile app requires a proper consideration of some predicting success factors which are discussed in the next section.

\subsection{Predicting Success Factors (PSFs) for Mobile Application Development}

The term PSFs implies certain necessary elements that contribute positively towards the success of any project (Toor and Ogunlana (2009), Hwang and Lim (2012)). These elements must be vital, beneficial and connect to the plan of achieving the project goal. Thus, to attain success in any project, one must first discover the significant factors that affect a project positively or negatively. In other words, the important factors to be considered for a project to be successful, otherwise failure will occur. A good understanding of the project, its environment and the development strategy will help to identify the PSFs. Besides the IT domain, research on the PSFs concept has been extensively conducted in other fields including medicine, construction and production industry (Toor and Ogunlana (2009)). Some of the predicting success factors identified for investigation under this study will be discussed next.

\subsubsection{Open Source Technology}

Open source technology enables the environment for peer programming by the collaboration of public developers, making the source code free to be used, modified and improved on. Open source is a critical 
component to achieve agility in mobile apps development (Rodrigues et al. (2010), Holzer and Ondrus (2011), Hesselman et al. (2009)).

\subsubsection{Individual Development Skills}

It requires innovative skills (Huntley (2011)), teamwork (Licorish and MacDonell (2017), interactive ability (Capretz and Ahmed (2010)), cognitive reasoning (Ahmed et al. (2012)), and good mental representation (Ahmed et al. (2013)) to develop successful software. Hence, mobile apps created by a team of software experts and a team staffed with skilled individuals will be more successful (Siau et al. (2010)).

\subsubsection{Software Development Kit}

A software development kit (SDK) provides tools for the development community and the required resources to developers during mobile apps development. Therefore, SDKs is a predicting success factor of mobile apps development (Wasserman (2010), Rodrigues et al. (2010), Gavalas and Economou (2011), Dalmasso et al. (2013), Charland and Le Roux (2011)).

\subsubsection{Portability}

The fact that mobile apps can be ported successfully from one device to another using a common platform makes it easily accepted by the community of users; hence portability has an effect on mobile apps development (Wasserman (2010), Gavalas and Economou (2011), Mahesh et al. (2012), Ahern (2009)).

\subsubsection{Functionality}

The functionality of a mobile app requires that it must meet the functional requirements of the users (Wasserman (2010, Gavalas and Economou (2011), Ally and Tsinakos (2014), Zhou et al. (2011)). If a mobile app does not meet the needs and expectations of the users, it will not be adopted into use; hence functionality is a factor to be considered in the mobile apps development.

\subsubsection{Back-end Integration}

The development of a mobile app requires the integration of the new application with the organization's existing applications and database infrastructure to produce similarly efficient, effective, user-friendly implementation of the existing systems. Hence back-end integration is considered to be a success factor of mobile apps development (He and Xu (2014), Unhelkar and Murugesan (2010)).

\subsubsection{System Development Methodology (SDM)}

The development of mobile apps requires the use of a systems development methodology (Okonkwo and Huisman (2018)). To achieve success in mobile apps development, it is important to adopt an SDM that best suits the need and requirements of the organizational project (Wasserman (2010), Corral et al. (2013), Partsch (2012), Huisman and Iivari (2006)).

\subsubsection{Mobile Device Specification Issues}

Mobile app developers are faced with very strict boundaries of mobile devices' specifications. In developing a mobile app, the specifications of the mobile devices specifications must be considered (Wasserman (2010), Unhelkar and Murugesan (2010), Vidas et al. (2011), Nosrati et al. (2012), Dehlinger and Dixon (2011)).

\subsubsection{Web and Network Integration}

Web-based mobile apps allow the usage of online applications on mobile devices. One of the ways to distribute the mobile app software is through the websites, which allow users to retrieve information or access services via their handheld devices, therefore web and network integration are considered to be a success factor of mobile app development (Ahern (2009), Zhou et al. (2010), Perez (2010)).

The above success factors of mobile apps development will be measured in this study to determine their degree of importance to the success of mobile apps' development as perceived by the different types of organizations. 


\section{RESEARCH METHODOLOGY}

To achieve the goal of the study, a survey was conducted with a questionnaire as an instrument for data collection. The questionnaire comprised of three sections: background information, mobile apps development and success factors. With background information, we gained more insight into the respondent's core business area. The mobile apps section investigates how mobile apps development (MAD) is performed especially in South Africa. The last section of the questionnaire covered the success factors of MAD. We listed some success factors obtained from literature with some explanatory statements in relation to each factor. The participants were asked to rate the importance of these success factors and their explanatory questions accordingly. The questionnaire contained mostly closed-ended questions with a 5-point Likert scale rating of 1 (totally disagreed) to 5 (totally agreed).

Using a convenience sample, our targeted audience was mobile apps developers from various organizations. The organizations involved in this study were software development companies, financial companies, telecommunication companies, educational institutions and engineering companies. The organizations used for the research study were selected when they were 1) Software companies that are fully into the business of software development and 2) Other companies that develop their respective mobile apps for their operational services, hence they have in-house developers and ICT professionals that develop, maintain and sustain their mobile apps. The questionnaires were sent to the IT department and were completed by the software developers and the ICT professionals in each respective organization. Drop off and electronic methods were used to distribute the questionnaire. A total of 392 questionnaires were distributed to different respondents and 152 (38.8\%) responses were returned within May to August 2015 in South Africa. The responses comprise 131 drop off and 21 electronically completed questionnaires.

The participants who participated in the survey were from an extensively diverse background in IT services and were mostly software developers. They were comprised of 17 (11.2\%) managing directors, 23 $(15.1 \%)$ chief information officers, $21(13.8 \%)$ IT managers, $79(52 \%)$ software developers, 5 (3.3\%) system administrators and $7(4.6 \%)$ system analysts. Their respective organizations have been into mobile application development ranging from 1-5 years to above 10 years including $23(15.1 \%)$ of $1-5$ years, 51 (33.6\%) of 5-10 years, $66(43.4 \%)$ of above 10 years and $12(7.9)$ indicated that they have not be involved in mobile application development. Also, these participants have developed or were involved with the development of a number of mobile apps ranging from 1-10 apps to above 100 apps including $66(43.7 \%)$ of 1-10 apps, 34 (22.5\%) of 10-50 apps, 18 (11.9\%) of 50-100 apps, $30(19.9 \%)$ of above 100 apps, $3(2 \%)$ indicated that they have not yet developed a working mobile app and one did not respond at all.

\section{RESULTS}

All the responses were thoroughly examined to extract the data and statistical analysis was performed to determine the PSFs of MAD. On the part of PSF, multiple items were used to examine the research variables.

A descriptive analysis was performed to describe the frequency and percentage of responses from the study population. Cronbach alpha reliability analysis was used to compute reliability coefficients for each of the examining factors. The criterion for Cronbach's coefficient alpha for reliability is $\alpha \geq 0.6$ (Sethi and King (1991), Nunally and Bernstein (1978)). That is if the obtained $\alpha \geq 0.6$ then the data obtained of that item is reliable.In addition, the data were categorized and analysis of variance (ANOVA) was performed to determine if there is any difference or similarity between the categories in order to determine organizational perceptions on the relevance of each of the PSFs (Creech (2003)). The mean comparison was done according to Cohen's effect sizes (Cohen, 1988)) and the guidelines for interpreting the effect sizes (d values) are as follows: $\mathrm{d}=0.2$ (small effect); $\mathrm{d}=0.5$ (medium effect) and $\mathrm{d} \geq 0.8$ (large effect or practical significant).

The first objective of this study is to determine the perceptions of various organizations on the identified PSFs towards the development of mobile apps. The PSFs were examined using one general question and some explanatory questions to test the participant perception regarding the importance of each particular PSF. A 5-point Likert scale was used for measurement ranging from 1 (totally disagreed) to 5 (totally agreed). Factor analysis was performed on the individual items to minimize the number of data points. This resulted in 9 factors which corresponded with the identified PSFs. Testing the reliability of the identified factors, the Cronbach alpha coefficients range from 0.73 to 0.98 indicating that the identified predicting 
success factors were reliable. The results obtained from descriptive statistics and reliability analyses are shown in Table 1.

In Table 1 the results are ranked in descending order according to mean for each PSF. The rating of the importance of the predicting success factors shows that if a mean value is $\geq 3$ then the respondents agree that the factor has a significant influence on the success of mobile apps development. The findings indicate that 8 out of 9 identified predicting success factors emerged as important regarding mobile apps development (minimum response mean $\geq 3.68$ ), while one did not. The three most important PSFs are individual development skills, functionality, and mobile devices specifications. The respondents did not perceive that the use open source technology is an important PSF for mobile application development success.

The results compare well with the report of the previous researches (Wasserman (2010), He and Xu (2014), Capretz and Ahmed (2010), Ahmed et al. (2013), Siau et al. (2010), Perez (2010)) even though the investigations were conducted in different environments. That is, this study agreed with the previous studies performed in a different context that the 8 factors are important predicting success factors of mobile apps development.

Table 1. Perceived Importance and Ranking of PSF for Mobile Application Development

\begin{tabular}{|c|c|c|c|c|c|c|c|c|c|}
\hline \multirow{2}{*}{ PSF } & \multirow{2}{*}{$\begin{array}{l}\text { Mean } \\
N=152\end{array}$} & \multirow{2}{*}{$\begin{array}{l}\text { Std. } \\
\text { Dev. }\end{array}$} & \multicolumn{5}{|c|}{ Scale rating } & \multirow{2}{*}{ 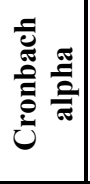 } & \multirow{2}{*}{$\begin{array}{l}\text { PSF } \\
\text { Rank }\end{array}$} \\
\hline & & & 1 & 2 & 3 & 4 & 5 & & \\
\hline $\begin{array}{l}\text { Individual } \\
\text { development } \\
\text { skills }\end{array}$ & 4.60 & 0.99 & 0 & 0 & 0 & $\begin{array}{c}61 \\
(40.1 \%)\end{array}$ & $\begin{array}{c}91 \\
(60 \%)\end{array}$ & 0.83 & 1 \\
\hline Functionality & 4.55 & 0.57 & 0 & $\begin{array}{c}1 \\
(0.7 \%)\end{array}$ & $\begin{array}{c}3 \\
(2 \%)\end{array}$ & $\begin{array}{c}59 \\
(38.8 \%)\end{array}$ & $\begin{array}{c}89 \\
(58.6 \%)\end{array}$ & 0.96 & 2 \\
\hline $\begin{array}{l}\text { Mobile } \\
\text { devices } \\
\text { specifications }\end{array}$ & 4.20 & 0.62 & 0 & 0 & $\begin{array}{c}17 \\
(11.2 \%)\end{array}$ & $\begin{array}{c}87 \\
(57.2)\end{array}$ & $\begin{array}{c}48 \\
(31.6 \%)\end{array}$ & 0.93 & 3 \\
\hline $\begin{array}{l}\text { Software } \\
\text { development } \\
\text { kit }\end{array}$ & 4.00 & 0.76 & 0 & 0 & $\begin{array}{c}1 \\
(0.7 \%)\end{array}$ & $\begin{array}{c}61 \\
(40.1 \%)\end{array}$ & $\begin{array}{c}90 \\
(59.2 \%)\end{array}$ & 0.98 & 4 \\
\hline $\begin{array}{l}\text { Back-end } \\
\text { integration }\end{array}$ & 3.89 & 0.71 & 0 & $\begin{array}{c}3 \\
(2 \%)\end{array}$ & $\begin{array}{c}38 \\
(25 \%)\end{array}$ & $\begin{array}{c}83 \\
(54.6 \%)\end{array}$ & $\begin{array}{c}28 \\
(18.4 \%)\end{array}$ & 0.95 & 5 \\
\hline Portability & 3.84 & 0.80 & 0 & $\begin{array}{c}9 \\
(5.9 \%)\end{array}$ & $\begin{array}{c}36 \\
(23.7 \%)\end{array}$ & $\begin{array}{c}78 \\
(51.3 \%)\end{array}$ & $\begin{array}{c}29 \\
(19.1 \%)\end{array}$ & 0.97 & 6 \\
\hline $\begin{array}{l}\text { Web and } \\
\text { network } \\
\text { integration }\end{array}$ & 3.76 & 0.79 & 0 & $\begin{array}{c}9 \\
(5.9 \%)\end{array}$ & $\begin{array}{c}42 \\
(27.6 \%)\end{array}$ & $\begin{array}{c}77 \\
(50.7 \%)\end{array}$ & $\begin{array}{c}24 \\
(15.8 \%)\end{array}$ & 0.98 & 7 \\
\hline $\begin{array}{l}\text { System Dev. } \\
\text { methodology }\end{array}$ & 3.68 & 0.63 & 0 & $\begin{array}{c}4 \\
(2.6 \%)\end{array}$ & $\begin{array}{c}49 \\
(32.5 \%)\end{array}$ & $\begin{array}{c}89 \\
(58.9 \%)\end{array}$ & $\begin{array}{c}9 \\
(6 \%)\end{array}$ & 0.93 & 8 \\
\hline $\begin{array}{l}\text { Open source } \\
\text { technology }\end{array}$ & 2.89 & 0.99 & $\begin{array}{c}13 \\
(8.6 \%)\end{array}$ & $\begin{array}{c}38 \\
(25.2 \%)\end{array}$ & $\begin{array}{c}58 \\
(38.4 \%)\end{array}$ & $\begin{array}{c}36 \\
(23.8 \%)\end{array}$ & $\begin{array}{c}6 \\
(4 \%)\end{array}$ & 0.91 & 9 \\
\hline
\end{tabular}

The second objective of this study is to investigate whether there are differences between the different types of organizations' perceptions regarding the importance of the identified PSF of the development of mobile apps. The organizations were divided between 4 groups, namely software development companies (Group 1), financial companies (Group 2), educational institutions (Group 3) and telecommunication companies (Group 4). ANOVA was performed the test whether there are differences between these different types of organizations' perceptions regarding the importance of the identified PSF. The results obtained are shown in Table 2. 
Table 2. ANOVA Analysis of Core Business Area and Perceived Importance of PSF

\begin{tabular}{|c|c|c|c|c|c|c|c|c|c|c|}
\hline \multirow[t]{2}{*}{ PSF items } & \multirow{2}{*}{$\begin{array}{c}\text { Core business } \\
\text { area } \\
\text { (Grp 1-4) }\end{array}$} & \multirow{2}{*}{$\begin{array}{c}\text { No. of } \\
\text { respondent } \\
\text { s }\end{array}$} & \multirow[t]{2}{*}{$\begin{array}{c}\text { Mea } \\
\text { n }\end{array}$} & \multirow[t]{2}{*}{$\begin{array}{l}\text { Std. } \\
\text { dev. }\end{array}$} & \multirow[t]{2}{*}{ F-value } & \multirow[t]{2}{*}{ p-value } & \multicolumn{4}{|c|}{$\begin{array}{l}\text { Tukey significance and } d- \\
\text { value for the Groups }\end{array}$} \\
\hline & & & & & & & 1 & 2 & 3 & 4 \\
\hline $\begin{array}{l}\text { Individual } \\
\text { developer } \\
\text { skills }\end{array}$ & $\begin{array}{l}\text { Grp. } 1 \\
\text { Grp. } 2 \\
\text { Grp. } 3 \\
\text { Grp. } 4\end{array}$ & $\begin{array}{l}85 \\
18 \\
21 \\
16\end{array}$ & $\begin{array}{l}4.49 \\
4.65 \\
4.48 \\
4.48\end{array}$ & $\begin{array}{l}0.47 \\
054 \\
0.51 \\
0.56\end{array}$ & $\begin{array}{c}0.54 \\
(3: 136)\end{array}$ & 0.6532 & & 0.28 & $\begin{array}{l}-.0 .04 \\
-0.32\end{array}$ & $\begin{array}{c}-0.03 \\
- \\
.0 .30 \\
0.01\end{array}$ \\
\hline Functionality & $\begin{array}{l}\text { Grp. } 1 \\
\text { Grp. } 2 \\
\text { Grp. } 3 \\
\text { Grp. } 4 \\
\end{array}$ & $\begin{array}{l}85 \\
18 \\
21 \\
16 \\
\end{array}$ & $\begin{array}{l}4.37 \\
4.56 \\
4.10 \\
4.63 \\
\end{array}$ & $\begin{array}{l}0.48 \\
0.47 \\
0.30 \\
0.45 \\
\end{array}$ & $\begin{array}{c}5.26 \\
(3: 136)\end{array}$ & 0.0018 & & 0.39 & $\begin{array}{l}-0.58 \\
-0.98\end{array}$ & $\begin{array}{l}0.53 \\
0.15 \\
1.17\end{array}$ \\
\hline $\begin{array}{l}\text { Mobile } \\
\text { devices } \\
\text { specifications }\end{array}$ & $\begin{array}{l}\text { Grp. } 1 \\
\text { Grp. } 2 \\
\text { Grp. } 3 \\
\text { Grp. } 4 \\
\end{array}$ & $\begin{array}{l}85 \\
18 \\
21 \\
16 \\
\end{array}$ & $\begin{array}{l}4.17 \\
4.42 \\
4.29 \\
4.59 \\
\end{array}$ & $\begin{array}{l}0.54 \\
0.73 \\
0.62 \\
0.49 \\
\end{array}$ & $\begin{array}{c}2.94 \\
(3: 136)\end{array}$ & 0.0353 & & 0.34 & $\begin{array}{c}0.18 \\
-0.18\end{array}$ & $\begin{array}{l}0.79 \\
0.24 \\
0.49\end{array}$ \\
\hline $\begin{array}{l}\text { Software } \\
\text { development } \\
\text { kit }\end{array}$ & $\begin{array}{l}\text { Grp. } 1 \\
\text { Grp. } 2 \\
\text { Grp. } 3 \\
\text { Grp. } 4 \\
\end{array}$ & $\begin{array}{l}85 \\
18 \\
21 \\
16 \\
\end{array}$ & $\begin{array}{l}4.10 \\
3.81 \\
3.48 \\
4.13 \\
\end{array}$ & $\begin{array}{l}0.70 \\
0.68 \\
0.60 \\
0.79 \\
\end{array}$ & $\begin{array}{c}5.15 \\
(3: 136)\end{array}$ & 0.0021 & & $-\overline{4}$ & $\begin{array}{l}-0.90 \\
-0.50\end{array}$ & $\begin{array}{l}0.03 \\
0.39 \\
0.82\end{array}$ \\
\hline $\begin{array}{l}\text { Back-end } \\
\text { integration }\end{array}$ & $\begin{array}{l}\text { Grp. } 1 \\
\text { Grp. } 2 \\
\text { Grp. } 3 \\
\text { Grp. } 4 \\
\end{array}$ & $\begin{array}{l}85 \\
18 \\
21 \\
16 \\
\end{array}$ & $\begin{array}{l}3.80 \\
4.31 \\
3.94 \\
4.46 \\
\end{array}$ & $\begin{array}{l}0.75 \\
0.58 \\
0.55 \\
0.58 \\
\end{array}$ & $\begin{array}{c}5.97 \\
(3: 136)\end{array}$ & 0.0008 & & 0.69 & $\begin{array}{c}0.18 \\
-0.66\end{array}$ & $\begin{array}{l}0.88 \\
0.25 \\
0.90\end{array}$ \\
\hline Portability & $\begin{array}{l}\text { Grp. } 1 \\
\text { Grp. } 2 \\
\text { Grp. } 3 \\
\text { Grp. } 4 \\
\end{array}$ & $\begin{array}{l}85 \\
18 \\
21 \\
16 \\
\end{array}$ & $\begin{array}{l}3.82 \\
4.26 \\
3.94 \\
3.98 \\
\end{array}$ & $\begin{array}{l}0.81 \\
0.64 \\
0.78 \\
0.78 \\
\end{array}$ & $\begin{array}{c}1.66 \\
(3: 136)\end{array}$ & 0.1788 & & 0.55 & $\begin{array}{c}0.15 \\
-0.41\end{array}$ & $\begin{array}{c}0.20 \\
-0.36 \\
0.05\end{array}$ \\
\hline $\begin{array}{l}\text { Web and } \\
\text { network } \\
\text { integration }\end{array}$ & $\begin{array}{l}\text { Grp. } 1 \\
\text { Grp. } 2 \\
\text { Grp. } 3 \\
\text { Grp. } 4 \\
\end{array}$ & $\begin{array}{l}85 \\
18 \\
21 \\
16 \\
\end{array}$ & $\begin{array}{l}3.58 \\
4.07 \\
3.57 \\
4.31 \\
\end{array}$ & $\begin{array}{l}0.70 \\
0.85 \\
0.87 \\
0.56 \\
\end{array}$ & $\begin{array}{c}6.13 \\
(3: 136)\end{array}$ & 0.0006 & & 0.57 & $\begin{array}{l}-0.01 \\
-0.58\end{array}$ & $\begin{array}{l}1.04 \\
0.28 \\
0.85\end{array}$ \\
\hline $\begin{array}{l}\text { System } \\
\text { development } \\
\text { methodology }\end{array}$ & $\begin{array}{l}\text { Grp. } 1 \\
\text { Grp. } 2 \\
\text { Grp. } 3 \\
\text { Grp. } 4 \\
\end{array}$ & $\begin{array}{l}85 \\
18 \\
21 \\
16 \\
\end{array}$ & $\begin{array}{l}3.61 \\
3.97 \\
4.00 \\
3.78 \\
\end{array}$ & $\begin{array}{l}0.61 \\
0.61 \\
0.45 \\
0.58 \\
\end{array}$ & $\begin{array}{c}3.82 \\
(3: 136)\end{array}$ & 0.115 & & 0.60 & $\begin{array}{l}0.64 \\
0.05\end{array}$ & $\begin{array}{r}0.29 \\
-0.32 \\
-0.38\end{array}$ \\
\hline $\begin{array}{l}\text { Open source } \\
\text { technology }\end{array}$ & $\begin{array}{l}\text { Grp. } 1 \\
\text { Grp. } 2 \\
\text { Grp. } 3 \\
\text { Grp. } 4 \\
\end{array}$ & $\begin{array}{l}85 \\
18 \\
21 \\
16\end{array}$ & $\begin{array}{l}3.17 \\
3,29 \\
3.21 \\
3.34 \\
\end{array}$ & $\begin{array}{l}0.69 \\
0.56 \\
0.84 \\
0.85\end{array}$ & $\begin{array}{c}0.53 \\
(3: 136)\end{array}$ & 0.80 & & 0.17 & $\begin{array}{c}0.05 \\
-.0 .09\end{array}$ & $\begin{array}{l}0.02 \\
0.06 \\
0.15\end{array}$ \\
\hline
\end{tabular}

Table 2 indicates some statistically significant differences in the perceived importance of five of the PSF (functionality, mobile device specifications, software development kit, back-end integration, and web and network integration) from the perspectives of the different types of organizations. When one considers functionality, there is a practical significant difference between the perceptions of financial companies and educational institutions, and also between educational institutions and telecommunication companies. Considering mobile device specifications, there is a practical significant difference between the perceptions of software development companies and telecommunication organizations. There is a practical significant difference in the perception of the importance of the use of a software development kit in mobile apps development between software development organizations and educational institutions, and also between educational institutions and telecommunication companies. Regarding back-end integration, there is a practical significant difference between the perceptions of software development companies and telecommunication organizations, and also between educational institutions and telecommunication companies. Considering web and network integration, there is a practical significant difference between the perceptions of software development companies and telecommunication organizations, and also between educational institutions and telecommunication companies. 
No statistical difference in the perception of the other PSFs like individual development skills, portability, use of a system development methodology and open source technology were found.

Although the PSFs are important in mobile apps development (excluding the use of open source technology), the different types of organizations value them differently. This may be because of the nature of their business and their need for mobile apps.

\section{CONCLUSION}

This study determined the predicting success factors and the degree of importance of these factors from the perspectives of various organizations on mobile apps development in South Africa. Through a survey, quantitative data was collected, empirically evaluated and the necessary results were obtained. The findings showed that individual development skills, functionality, mobile devices specifications, use of a software development kit, back-end integration, portability, web and network integration, and the use of a system development methodology are the predicting success factors of mobile apps development whereas open source technology is not. Although these factors are general and have been proven to be important in other context or countries, this study justified their importance in a different contextual environment of South Africa. Depending on their objectives and purposes, different organizations have different perceptions of the relevance of these factors. In terms of applications, mobile apps developers and organizations will use these factors as the baseline to know the most appropriate factors to be considered to achieve success in any mobile apps development project. Further study will be oriented towards the identification of new factors that may emerge as technology advances and expand the scope of the research.

\section{REFERENCES}

Ahern, K., 2009. Critical success factors for commercial mobile application. http://www.slideshare.net/keithahern/critical-success-factors-for-commercial-mobile-applications-or-how-to-put-bigideas-into-small-devices.

Ahmed, F. et al. 2012. Evaluating the demand for soft skills in software development. IT Professional, Vol. 14, No. 1, pp. 44-49.

Ahmed, F., et al., 2013. Soft Skills and Software Development: A Reflection from Software Industry. International Journal of Information Processing and Management, Vol. 4, No. 3, pp. 171-191.

Ally, M. and Tsinakos, A., 2014. Increasing access through mobile learning. Commonwealth of Learning, Vancouver.

Capretz, L.F. and Ahmed, F., 2010. Making sense of software development and personality types. IT professional, Vol. 12, No. 1, pp. 6-13.

Charland, A. and Le Roux, B., 2011. Mobile application development: web vs. native. Communications of the ACM, Vol. 54, No. 5, pp. 49-53.

Chatterjee, S., et al., 2009. Examining the success factors for mobile work in healthcare: A deductive study. Decision Support Systems, Vol. 46, No. 3, pp. 620-633.

Cohen, J., 1988. Statistical power analysis for the behavioural sciences (2nd ed). Hillsdale, NJ: Erlbaum.

Corral, L., et al., 2013. Software development processes for mobile systems: Is agile really taking over the business? 1st International Workshop on the Engineering of Mobile-Enabled Systems (MOBS). 10.1109/MOBS.2013.6614218.

Creech, S., 2003. Statistically significant. http://www.statisticallysignificantconsulting.com/Anova.htm.

Dalmasso, I., et al. 2013. Survey, comparison and evaluation of cross platform mobile application development tools. 9th IEEE International Wireless Communications and Mobile Computing Conference (IWCMC), July 1-5, 2013, Cagliari, Italy.

Dehlinger, J. and Dixon, J., 2011. Mobile application software engineering: Challenges and research directions. Workshop on Mobile Software $\quad$ Engineering. https://pdfs.semanticscholar.org/3ffc/4f867e45f8c8e9019726b351172ed77aca4f.pdf

El-Hussein, M.O.M. and Cronje, J.C., 2010. Defining Mobile Learning in the Higher Education Landscape. Educational Technology \& Society, Vol. 13, No. 3, p p. 12-21.

Feng, H., et al., 2006. Exploring the critical success factors for mobile commerce. ICMB'06. International Conference on Mobile Business, Copenhagen, Denmark.

Gavalas, D. and Economou, D., 2011. Development platforms for mobile applications: Status and trends. IEEE software, Vol. 28, No. 1, pp. 77-86.

GSMA, 2015. The mobile economy Sub-Saharan Africa 2015. GSMA Intelligence. Regional report https://gsmaintelligence. com/research. 
$\mathrm{He}$, W. and Xu , L., (2014). Integration of distributed enterprise applications: A survey. IEEE Transactions on Industrial Informatics, Vol. 10, No. 1, pp. 35-42.

Hellström, J. and Tröften, P.E., 2010. The innovative use of mobile applications in East Africa. Swedish international development cooperation agency (Sida).

Hesselman, C., et al., 2009. Interactive TV Together: An Open Service Infrastructure for Enhancing Interactive TV Experiences. Social Interactive Television: Immersive Shared Experiences and Perspectives. IGI Global. pp. 30-49.

Holzer, A. and Ondrus, J., 2011. Mobile application market: A developer's perspective. Telematics and informatics, Vol. 28, No. 1, pp. 22-31.

Huisman, M. and Iivari, J., 2006. Deployment of systems development methodologies: Perceptual congruence between IS managers and systems developers. Information \& Management, Vol. 43, No. 1, pp. 29-49.

Huntley, C.L., 2011. Onshore Mobile App Development: Successes and Challenges. Computer, Vol. 44, No. 9, pp. 102-104.

Hwang, B.G. and Lim, E.S.J., 2012. Critical success factors for key project players and objectives: Case study of Singapore. Journal of Construction Engineering and Management, Vol. 139, No. 2, pp. 204-215.

Licorish, S.A. and MacDonell, S.G. 2017. Exploring software developers' work practices: Task differences, participation, engagement, and speed of task resolution. Information \& Management, Vol. 54, No. 3, pp. 364-382.

Mahesh, B.R., et al. 2012. Portability of mobile applications using phonegap: A case study. International Conference on Software Engineering and Mobile Application Modelling and Development (ICSEMA 2012), pp. 1-6. 10.1049/ic.2012.0156.

McNamara, K.S., 2009, Mobile Applications in Agriculture and Rural Development-Framing the Topic, and Learning from Experience. World Bank Workshop on Mobile Innovations for Social and Economic Transformation.

Murugesan, S., 2013. Mobile apps in Africa. IT Professional, Vol. 15, No. 5, pp. 8-11.

Mutula, S.M. and Mostert, J., 2010. Challenges and opportunities of e-government in South Africa. The Electronic Library, Vol. 28, No. 1, pp. 38-53.

Noor, M.M., 2011. Determining critical success factors of mobile banking adoption in Malaysia. Australian Journal of Basic and Applied Sciences, Vol. 5, No. 9, pp. 252-265.

Nosrati, M. et al., 2012. Mobile computing: principles, devices and operating systems. World Applied Programming,

Vol. 2, No. 7, pp. 399-408.

Nunally, J.C. and Bernstein, I.H., 1978. Psychometric theory. McGraw-Hill, New York.

Okonkwo, W.C. and Huisman, M., 2018. The Use of System Development Methodologies in the Development of Mobile Applications: Are they Worthy of Use? IEEE 42nd Annual Computer Software and Applications Conference (COMPSAC), Tokyo, Japan, pp. 278-283.

Olavsrud, T., 2012. 10 Top Mobile Application Development Platforms. Network World. http://www.networkworld.com/article/2286706/4g/10-top-mobile-application-development-platforms.html.

Papanikolaou, K. and Mavromoustakos.,S., 2006. Critical Success Factors for the Development of Mobile Learning Applications. EuroIMSA, Innsbruck, Austria.

Partsch, H.A., 2012. Specification and transformation of programs: a formal approach to software development. Springer Science \& Business Media.

Perez, S., 2010. 10 distribution channels for mobile applications. http://readwrite.com/2010/11/17/10-distributionchannels-for-mobile-apps.

Qiang, C.Z., et al., 2011. Mobile applications for agriculture and rural development. World Bank, Washington, DC.

Rodrigues, J.J. et al, 2010. New trends on ubiquitous mobile multimedia applications. EURASIP Journal on Wireless Communications and Networking, No.1, pp. 1-11.

Siau, K. et al. 2010. Important characteristics of software development team members: an empirical investigation using Repertory Grid. Information Systems Journal, Vol. 20, No. 6, pp. 563-580.

Sethi, V. and King, W.R., 1991. Construct measurement in information systems research: An illustration in strategic systems. Decision Sciences, Vol. 22, No. 3, pp. 455-472.

Toor, S.-u.-R. and Ogunlana, S.O., 2009. Construction professionals' perception of critical success factors for large-scale construction projects. Construction Innovation, Vol. 9, No. 2, pp. 149-167.

Unhelkar, B. and Murugesan, S., 2010. The enterprise mobile applications development framework. IT professional, Vol 12, No. 3, pp. 33-39.

Vidas, T. et al., 2011. Toward a general collection methodology for Android devices. Digital investigation, Vol. 8, pp. 14-24.

Wasserman, A.I., 2010, Software engineering issues for mobile application development. Proceedings of the FSE/SDP workshop on Future of software engineering research, FoSER 2010, November 7-8, 2010, Santa Fe, New Mexico, USA.

Zhou, T. et al. 2010. Integrating TTF and UTAUT to explain mobile banking user adoption. Computers in human behavior, Vol. 26, No. 4, pp. 760-767.

Zhou, Y., et al. 2011. Taming information-stealing smartphone applications (on Android). Trust and Trustworthy Computing. Trust 2011. Lecture Notes in Computer Science, vol 6740. Springer, Berlin, Heidelberg. 